\author{
Graeme Gill \\ The University of Sydney \\ graeme.gill@sydney.edu.au
}

\title{
The Russian Revolution After One Hundred Years
}

\begin{abstract}
The Russian revolution was the defining episode of the twentieth century. It led to the transformation of Russia into one of the superpowers on the globe, but one that exhibited a development model that was both different from and a challenge to the predominant model in the West. The Soviet experiment offered a different model for organising society. This was at the basis of the way in which international politics in the whole post-second world war period was structured by the outcome of the Russian revolution. But in addition, that revolution helped to shape domestic politics in the West in very significant ways. All told, the revolution was of world historical and world shaping importance.
\end{abstract}

Key words: cold war; communism; development models; left-wing politics; Russian revolution; socialism

After one hundred years, the Russian revolution remains a matter of vigorous scholarly contention. Although in the eyes of many the evaluative question has been settled-the system of communism created by the revolution has failed-the question of how the revolution is to be understood remains a hot topic, as many of the publications that have come out around the centenary show. Is the revolution best seen as part of the general imperial collapse resulting from the First World War? ${ }^{1}$ Should it be seen as part of a European (Germany, Hungary) or a Eurasian (China, Iran, Turkey) wave of revolution? ${ }^{2}$ Some writers focus on the February revolution and its antecedents, ${ }^{3}$ some on the year 1917.4 Other authors frame the revolution as lasting up to 1921 and the New Economic Policy (NEP) 5 or to the late 1920 s when Stalin launched his "revolution from above". ${ }^{6}$ And many of the questions that have long agitated scholars remain; for example, was structure or agency more important, what was the role of German gold,

\footnotetext{
${ }^{1}$ Joshua A. Sanborn, Imperial Apocalypse. The Great War and the Destruction of the Russian Empire, Oxford: Oxford University Press, 2014 and Robert Gerwarth \& Erez Manela (eds), Empires at War 1911-1923, Oxford: Oxford University Press, 2014.

${ }^{2}$ For a two volume study focusing on the latter context, see Joseph A. Rieber, The Struggle for the Eurasian Borderlands. From the Rise of Early Modern Empires to the End of the First World War, Cambridge: Cambridge University Press, 2014, and Stalin and the Struggle for Supremacy in Eurasia, Cambridge: Cambridge University Press, 2015.

3 Semion Lyandres, The Fall of Tsarism. Untold Stories of the February Revolution, Oxford: Oxford University Press, 2013, and Dominic Lieven, The End of Tsarist Russia. The March to World War One and Revolution, New York: Viking, 2015.

4 China Miéville, October. The Story of the Russian Revolution, London: Verso, 2017, and Helen Rappaport, Caught in the Revolution. Petrograd 1917, London: Windmill Books, 2016.

5 Sean McMeekin, The Russian Revolution. A New History, London: Profile Books, 2017.

${ }^{6}$ S.A. Smith, Russia in Revolution. An Empire in Crisis 1890 to 1928, Oxford: Oxford University Press, 2017.
} 
how important were the peasantry, and could the Provisional Government have avoided October? So the revolution remains an important matter of scholarly concern.

However the revolution's centenary has not enjoyed much public resonance in the West. Despite scholarly publications, conferences and seminars, there has been little in the way of public or official acknowledgement. Even in Russia, the home of the revolution and the core of the Soviet experiment, there has been no major marking of the centenary. On Putin's direction, ${ }^{7}$ an organising committee was established in the Russian Historical Society with a brief to organise events surrounding the centenary, and it drew up a program of 118 events. ${ }^{8}$ However no national commemoration was organised. The anniversary of the February revolution passed without ceremony or celebration, while the events marking October were organised by the communist party rather than the state. This reflects official ambiguity about how the Soviet period fits into an emergent national narrative. One view as enunciated by President Vladimir Putin is that the collapse of the Soviet Union was the greatest geopolitical catastrophe of the twentieth century 9 because of the way in which it led to economic dislocation and hardship for the Russian people. The official view, such as it is, is that the Soviet period was one of great achievements but at extremely high cost, and that those achievements (especially victory in the war) should be celebrated; there is less enthusiasm for delving too deeply into the costs. This judgement has been explicit from Putin's comments on the eve of taking up the presidency when he acknowledged the "unquestionable achievements" of the Soviet period but also the outrageous price and "historic futility"; communism was, he said, "a blind alley, far from the mainstream of civilisation." 10

The problem the revolution poses for Putin is multi-dimensional. As the regime tries to mould a heroic narrative of the Russian past to feed into its legitimation program, ${ }^{11}$ it seeks to wed aspects of the tsarist pre-Soviet era with the achievements of Soviet socialism. The revolution and the regime it produced, representing a rejection of tsarist Russia, fit awkwardly into this process. How can the undoubted achievements like industrialisation and victory in the war be included in a triumphalist national narrative when communism was also a "dead end" 12 that produced widespread unnecessary death and suffering? ${ }^{13}$ Striking the right balance is difficult, and therefore better not seek to try by largely ignoring the centenary, at least in a national symbolic fashion. Furthermore any glorification of revolution and popular mobilisation in the streets would sit awkwardly with Putin's preoccupation with "colour revolution" and the

\footnotetext{
7 “Podpisano rasporiazhenie o provedenii meropriiatii k 100-letiiu revoliutsii 1917g”, 19 December 2016. www.rushistory.org (accessed 21 September 2017)

8 These comprised exhibitions, publications, lectures, conferences and some media events. "Plan osnovnykh meropriiatii, sviazannykh so 100-letiem revoliutsii 1917 goda v Rossii” www.rushistory.org (accessed 21 September 2017)

9 Vladimir Putin, "Poslanie Federal'nomu sobraniiun Rossiiskoi federatsii”, 25 April 2005,

archive.kremlin.ru/appears/2005/o4/25/1223_type63372type63374type82634_87049.shtml (accessed 14 January 2012)

${ }_{10}$ Vladimir Putin, "Rossiia na rubezhe tysiacheletii”, Nezavisimaia gazeta 30 December 1999. This evaluation was also found in a number of his annual addresses to the Federal Assembly, and by Medvedev when he was president. For example, Medvedev's comments on the Remembrance Day of the Victims of Political Repression in 2009. www.kremlin.ru (accessed 30 October 2009)

${ }^{11}$ On this see Graeme Gill, Symbolism and Regime Change in Russia, Cambridge: Cambridge University Press, 2013 , ch.5.

12 For example, see Putin's comments in Nezavisimaia gazeta 30 December 1999 and 6 September 2004, and Komsomol'skaia Pravda 7 May 2005.

13 For example, see Putin's comments in Vremia novostei 13 October 2007.
} 
dangers he sees this holds for the regime. ${ }^{14}$ So the official Russian attitude remains ambiguous.

For the communists in Russia, the position is clear: the revolution is something that should be celebrated, it ushered in the building of a glorious future personified by Stalin, and it was cruelly destroyed by internal traitors. ${ }^{15}$ Among the populace, the view is mixed. For both conservatives and the liberal opposition, the revolution and subsequent Soviet period was a disaster. For many among the conservatives, including the Russian Orthodox Church, the revolution marked the end of the monarchy and a system which, they believed, was fully in tune with Russian culture and history, and should be restored. ${ }^{16}$ Liberals were appalled by the illegality and lack of freedom that was ushered in during Soviet times, seeing it as pushing Russia away from the main path of human development. ${ }^{17}$ More broadly, many feel a nostalgia for aspects of the Soviet period without necessarily wanting to restore Soviet rule, ${ }^{18}$ while many of the younger generation simply remain largely ignorant and apathetic; the Soviet period and the revolution that brought it about do not register on their horizons. So, apart from the communists, there has been no groundswell of popular support for remembering the revolution.

Given the diversity of approaches to the revolution, how should we see it now, one hundred years on? In my view, it was the defining episode of the twentieth century. It was the revolution that set Russia on the particular path it was to follow for 74 years, and that shaped both global politics and the domestic politics of a large number of states, including the main Western ones. In this sense, the revolution was a centurydefining, world historic event.

\section{The Revolution and Russia}

The revolution involved the collapse of the 300 year old Romanov dynasty, and the monarchical system that had dominated Russia for hundreds of years before that, and, after an interregnum of some eight months, brought the Bolsheviks to power. Having consolidated themselves in power, they then introduced a program of sustained socioeconomic change which had industrialisation at its heart and raised the country to the level of a superpower within two generations. Had the revolution not occurred and the tsar continued to reign, Russia would still have industrialised, but it is a moot point as to whether it would have achieved the same levels as the Soviet program did in the same timescale. This argument, about whether the revolution was a long-term stimulus to Russian economic development or a major impediment to it, was a significant field of conflict between supporters and opponents of the revolution. ${ }^{19}$ But all agreed that

\footnotetext{
14 For an analysis of this and how it has affected Russian policy, see Robert Horvath, Putin's Preventive CounterRevolution. Post-Soviet authoritarianism and the spectre of velvet revolution, London: Routledge, 2013.

15 For the views of the party leader, see Gennadii Ziuganov, Stalin i sovremennost', Moscow: Molodaia gvardiia, 2009.

${ }^{16}$ Representative of this view was the novelist, Alexander Solzhenitsyn. Alexander Solzhenitsyn, Rebuilding Russia, Reflections and Tentative Proposals, London: Harvill, 1991.

17 For one example, see Egor Gaidar, Gosudarstvo i evoliutsiia, Moscow: Evraziia, 1995.

${ }^{18}$ For aspects of this see Serguei Alex. Oushakine, “'We're Nostalgic But We're Not Crazy': Retrofitting the Past in Russia”, Russian Review 66, 3, 2007, pp.451-482; Serguei Alex. Oushakine, The Patriotism of Despair. Nation, War, and Loss in Russia, Ithaca: Cornell University Press, 2009; Svetlana Boym, The Future of Nostalgia, New York: Basic Books, 2001.

19 For some approaches to this question, see two essays by Alexander Gerschenkron, "Economic Backwardness in Historical Perspective" and "Russia: Patterns and Problems of Economic Development, 1861-1958”, Alexander Gerschenkron, Economic Backwardness in Historical Perspective, Cambridge [Mass]: The Belknap Press, 1962,
} 
the Soviet program was very different from what a tsarist regime would have been likely to pursue.

Central to the Soviet project was the desire to create a completely new civilisation based on a new type of socio-economic system. The Bolsheviks did not talk about it in such civilisational terms, ${ }^{20}$ but that is what they meant when they talked about the building of socialism/communism. Their openly espoused aim was the creation of a society characterised by freedom and equality, one in which the alienation and degradation of capitalism were superseded by the introduction of a socialist way of life characterised by the absence of exploitation and the presence of freedom, equality and material abundance. Accordingly, they were not content simply to industrialise and to let society develop along with this. Instead they sought to shape all aspects of people's lives including what they believed, how they lived, and even how they spoke. Their aim was the fundamental transformation of society at all levels in an attempt to achieve essentially utopian goals. This aim clearly distinguished the post-revolutionary Soviet course from its potential tsarist competitor (at least as reflected in the tsarist development program in operation since the 1890s), as well as from what was happening elsewhere in the world; the Soviet regime was unique in its combination of transformative aim, highly centralised political and economic structures, and the extent of control the state sought to wield over society. Seeking nothing less than the creation of a "new Soviet man", the Soviet state generated its own unique brand of modernity that was in sharp contrast to that rooted in capitalism. ${ }^{21}$

Recognition of the idealistic aims behind the revolution has been obscured in the intervening century, principally because of the way that the Soviet enterprise fell far short of those ideals. Certainly there were many positive aspects of the Soviet experience: rising living standards, an established universal social and welfare net, the educational raising up of millions, rapid paced economic development, greater equality, the effective ending of illiteracy and unemployment, and the building of capacity that enabled victory in the Second World War. But there were also immense costs: the millions of dead over and above the course of natural attrition, ${ }^{22}$ the stunting of the personal development of millions of people, the marginalisation of individuals and whole communities, restrictions upon freedom of thought and action, the suppression of minority nationalism, corruption, widespread environmental degradation, and as enthusiasm turned to apathy the rise of alienation.

The question of inevitability, of whether revolution in an under-developed country inevitably led to such heavy costs of development including authoritarian rule was a significant major point of contention among post-war Western scholars. 23 This has always been an intensely political question: many on the right tended to argue that the revolution was not inevitable but once undertaken the Stalin dictatorship flowed

\footnotetext{
pp.5-30 \& 119-151, and Theodore Von Laue, Why Lenin? Why Stalin? A Reappraisal of the Russian Revolution, 1900-1930, Philadelphia: J.B. Lippincott Co., 1964.

${ }^{20}$ Although others have. For very different views, see Sidney \& Beatrice Webb, Soviet Communism. A New Civilisation, London: Victor Gollancz Ltd, 1937 and Stephen Kotkin, Magnetic Mountain. Stalinism as a Civilization, Berkeley: University of California Press, 1995.

${ }^{21}$ See David L. Hoffman, Stalinist Values. The Cultural Norms of Soviet Modernity 1917-1941, Ithaca: Cornell University Press, 2003, and David Hoffman \& Yanni Kotsonis (eds), Russian Modernity. Politics, Knowledge and Practices 180o-1950, Basingstoke: Palgrave Macmillan, 2000.

${ }^{22}$ For attempts to measure this, see Steven Rosefielde, Red Holocaust, London: Routledge, 2010, and Alexander Yakovlev, A Century of Violence in Soviet Russia, New Haven: Yale University Press, 2002.

${ }^{23}$ For one discussion of this inevitability debate, see Sheila Fitzpatrick, "What's Left?", London Review of Books 30 March 2017, pp.13-15.
} 
inevitably from it, while those on the left accepted the inevitability of the revolution but argued that the later dictatorship was conjunctural. The shorthand form this argument took was about the relationship between Lenin and Stalin: did Lenin and the system he established lead inevitably to Stalin? Those who argued for inevitability focused upon those of Lenin's writings emphasising centralisation, discipline, control and the use of force, and upon the suppression of non-Bolshevik forces after 1917 and of dissent in the party in 1921. Those disputing inevitability point to Lenin's writings regarding NEP and to the functioning of NEP itself, highlighting the way in which the "revolution from above" which ended NEP and created the conditions leading to the Terror really were a revolutionary turn away from what Lenin had created. ${ }^{24}$ Historiographically the debate remains open, but much of the steam has gone out of the argument because the answer no longer has relevance to the legitimation claims of the current Russian regime, unlike the Soviet.

Although those costs identified above were not inevitable, they were related to the initial idealism of the Bolsheviks. Animated by idealistic goals but in practice believing themselves confronted by enemies at every turn-Western imperialists, White guardists, bourgeois remnants, kulaks, enemies of the people-the rulers of the Soviet Union felt liberated from the constraints of "bourgeois morality". To achieve their overriding aim of building a new society, there was the widespread belief that anything was acceptable as long as it served that end. This was not a conclusion that all members of the Bolshevik elite came to easily (which is reflected in the debate over NEP ${ }^{25}$ ), but there were sufficient among them who did believe this and were able to win in the political conflict at the top of the regime so that they were able to set the tone for all. And here Stalin was central. The immense costs involved in winning the civil war, in the collectivisation of agriculture and forced-pace industrialisation, and the hardship and deaths associated with the unleashing of the so-called "Great Terror" in the 1930s, were all rationalised on the basis of "you can't make an omelette without cracking eggs". These costs were not the inevitable product of either the nature of the Bolshevik elite or of revolution in a backward society. They stemmed from the tension between the regime's ideals and the difficulty of achieving them. It was that tension that was instrumental both in Stalin coming to power, and in his gaining of broad-based support within the party to carry out the measures that he deemed essential. Whether those measures were objectively essential is another question. What is important was that Lenin and then Stalin was able to convince others that they were, and this was a function of the gap between Bolshevik ideals and reality on the ground. Given the gulf between the situation they found themselves in and the ideals they professed to want to realise, anything that would help to achieve this aim could appear justified.

So in terms of domestic development, nothing flowed ineluctably from the revolution. There were crucial conjunctural points in Soviet history when particular decisions were made that, had another choice been made, may have led down a very different path of development. Whether to establish a coalition government in 1917 or a single party government, whether to use terror tactics against the opposition, whether as Lenin seems to have argued toward the end of his life the NEP offered a viable path to

\footnotetext{
24 For an excellent discussion of the so-called "continuity thesis" which provides an extensive bibliography, see Stephen F. Cohen, "Bolshevism and Stalinism”, Robert C. Tucker (ed), Stalinism. Essays in Historical Interpretation, New York: W.W. Norton Co. Inc., 1977, pp.3-29. On the assumed role of authoritarian Russian culture, see Tibor Szamuely, The Russian Tradition, London: Secker \& Warburg, 1974.

25 For example, see Stephen F. Cohen, Bukharin and the Bolshevik Revolution. A Political Biography 1888-1938, London: Wildwood House, 1974.
} 
socialism, whether forced-pace industrialisation and agricultural collectivisation were appropriate means of building socialism, and whether the Terror was warranted, are all decisions that were not preordained, but which set the Soviet Union on a particular course. And all may be seen in terms of the reaction to the dissonance between the classic ideals and grubby reality. This sort of dissonance is common in revolutionary situations as idealism gets battered by the imperatives of holding power and ruling. For the Bolsheviks this dissonance was evident right from the start. Because Russia was not the advanced industrial country that had been envisaged in the Marxism that had shaped their outlook, even before the revolution Lenin had struggled to accommodate theory and practical reality as he saw it. The result was a revolution that more orthodox Marxists criticised as premature and bound to lead to dictatorship. ${ }^{26}$

Central to the Soviet experience and what made it so important, was that it ushered in a new development model, hitherto unseen. While the development model of the tsarist regime had the state playing a significant role in sponsoring industrial development, much of that development remained in private hands. ${ }^{27}$ As the Russian economy was taking off in the decades before the war, it was recognisably a capitalist economy with an autocratic political system. The model created by the Bolsheviks was very different. With all productive capacity-factories, farms, transport, communications - taken under state control and labour mobilisation a major element, the economy was clearly not a form of capitalism, at least insofar as that term was understood at that time. ${ }^{28}$ It was a system that came to be called "state socialist" by observers in the West. Politically, it was run by a new form of structure, a single party which sought to control all aspects of life. This combination of state control of the economy and party control of state and society was a new form of polity and one that stemmed from the Bolshevik drive toward societal transformation.

So while the fact of the revolution did not determine the course of subsequent Soviet development, it did bring to power the regime which visited these things on society. In the realm of counter-factual history, it is highly likely that without the revolution Russia would have followed a different developmental trajectory. Any regime in Russia after the First World War would have pursued a path of rapid industrialisation, but in the absence of Bolshevik ideology that path would likely have been different to that which was actually followed. It is unlikely that any non-Bolshevik rulers of Russia would have sought to abolish private property and to drive all development through the state, with the accompanying results of popular disaffection and institutional overload. Similarly, the Great Terror would have been unlikely had Stalin not come to power. ${ }^{29}$ So while the revolution brought the Bolshevik regime to power and set Russia on the path it was to follow for the next seven decades, the precise details of that path were not preordained by the revolution.

The Soviet development model had implications not just for Russia, but for the entire world.

\footnotetext{
${ }^{26}$ For example, Karl Kautsky, The Dictatorship of the Proletariat, Ann Arbor: The University of Michigan Press, 1971 and Rosa Luxemburg, The Russian Revolution and Leninism or Marxism?, Ann Arbor: University of Michigan Press, 1970.

27 See John Hobson, The Wealth of States. A Comparative Sociology of International Economic and Political Change, Cambridge: Cambridge University Press, 1997, ch.3.

28 Some later critics did label it "state capitalism". For example, Tony Cliff, State Capitalism in Russia, London: Pluto Press, 1974.

29 Unlikely but not impossible, as the widely divergent cases of Ivan the Terrible, Hitler and Pol Pot make clear.
} 


\section{The Revolution and International Politics}

From its establishment in 1917, the Soviet regime was faced by a hostile world. Immediately manifested by the outbreak of the civil war and the involvement of some of the Western powers on the anti-Bolshevik side, this soon settled into a situation of widespread international hostility to the new regime. Although justified initially by the Bolshevik withdrawal from the war and the refusal to meet the financial obligations that had been taken on by the tsarist regime, the real basis of the hostility lay in Moscow's perceived intentions. The Bolsheviks were open in their aim of overturning not just the established international order, but the domestic arrangements in the major countries of the West as well. Casting themselves as the vanguard of international socialist revolution, the Bolsheviks saw their task as being to promote such a development across the world, especially in the economically advanced countries of the West, with the establishment of the Communist International (Comintern) in 1919 reflective of this. Even when this proselytising zeal had in practice been replaced by a more status quo orientation designed to defend the Soviet state from its enemies, much of both the action and rhetoric emanating from Moscow was perceived in the West as being hostile and challenging. ${ }^{30}$

Western fears of Moscow stemmed not just from Soviet military might but from the way the communist movement spread across the world, including in their own countries. ${ }^{3}$ Central here was the challenge that the Soviet experiment seemed to pose to the way in which Western liberal capitalist society was ordered. The claim to be building a communist society which was in all respects superior to the capitalist one from which it emerged, was a clear challenge to the West because it suggested that there was a different, and far better, way of organising society. This appeared as a viable and to many people attractive alternative to the Western capitalist development model, and with it to the way in which power was distributed in Western societies, especially in light of the contrast between the way in which Western economies suffered from the effects of the Great Depression at precisely the same time that the Soviet economy was leaping forward under the first and second five year plans. The Soviet Union was thus seen as an ideological competitor, not simply a military one. And in the longer term this ideological aspect was much more important than the military because it involved an existential threat to the established way of doing things in the West; the complete transformation of society by a working class enthused by the Soviet example seemed potentially in the offing. ${ }^{32}$ Ruling circles in the West thus had a clear incentive to oppose the Soviet Union in order to consolidate the system upon which their power rested.

The reality of this challenge seemed for many to be reflected in the popular mobilisation onto the streets in many of the European cities in the 1930s.33 This was

\footnotetext{
$3^{30}$ For an early study by the person who did the most to shape initial post-war American policy towards the USSR, see George F. Kennan, Russia and the West Under Lenin and Stalin, New York: Mentor Books, 1960.

${ }^{31}$ For recent histories of international communism, see Archie Brown, The Rise and Fall of Communism London: The Bodley Head, 2009; Robert Harvey, Comrades. The Rise and Fall of World Communism, London: John Murray, 2003; A. James McAdams, Vanguard of the Revolution. The Global Idea of the Communist Party, Princeton: Princeton University Press, 2017; David Priestland, The Red Flag. Communism and the Making of the Modern World, London: Penguin, 2009; Robert Service, Comrades. Communism. A World History, London: Pan Books, 2008.

$3^{2}$ For a study of the "red scare" and its effects in the US, see Nick Fischer, Spider Web. The Birth of American Anticommunism, Urbana: University of Illinois Press, 2016.

33 For a stimulating study of this period, see Gregory M. Luebbert, Liberalism, Fascism, or Social Democracy. Social Classes and the Political Origins of Regimes in Interwar Europe, Oxford: Oxford University Pres, 1991.
} 
most apparent in events in Germany leading to the rise of Hitler. One aspect of this was fear of "communism". The clash between right and left on the streets of Germany, and the way in which the left was publicly presented by its opponents, tapped into the more general fear of socialism and communism that had already been evident in the suppression of the abortive German revolution in 1918-19. The fear of "communism" and the need to combat it was a continuing theme within elements of German society. It was also a consideration among some of the Western powers who saw a powerful Germany as being an important bulwark against the "Bolshevik menace".

Ultimately for the Western powers, the danger posed by Hitler was seen to be more immediate than that emanating from the Soviet Union, with the result that they reluctantly entered into an alliance with the USSR against Germany to wage war and defeat the fascist menace, a victory that would have been unlikely without the Soviet contribution. Paradoxically the Western liberal capitalism which the Soviet model had sought to transcend, was saved by the USSR. But the friendly relationship, which throughout was characterised by a lack of real trust, 34 did not last beyond the war's end.

The principal axis of international politics for the 45 years after the war was hostility between the Western powers and the Soviet Union. The expansion of Soviet power into east-central Europe, the coming to power of the communists in China and the outbreak of the Korean War all confirmed in the minds of leading Western politicians a picture of the Soviet Union as an aggressive, expansionist power. The response was the Truman doctrine which was designed officially to "contain" and later to "roll back" Soviet expansion. "Soviet expansionism" remained the paradigm through which Western policy-makers shaped foreign policy until 1989 and around which much of the global politics of this period turned. 35

In its most public form, the cold war was a military stand-off between two armed alliance systems: the North Atlantic Treaty Organisation confronted the Warsaw Treaty Organisation, with the principal line of friction running through central Europe. The relationship was highly militarised, and through the adherence of many countries outside Europe to one side or the other and the view of the non-aligned countries as possible arenas of competition, the confrontation was not just European but global in dimension. ${ }^{6}$ In few parts of the world was there not competition between the two sides. This global dimension of the competition reflects the way in which the Cold War was not simply another major power confrontation familiar from the past. The Cold War was different, and that difference stemmed essentially from the Russian revolution.

The Cold War was not only a military contest; it was an ideological and economic conflict as well. With the rationale of the communist system being the creation of a social order superior to that in the West, the stand-off between the two sides was at its

\footnotetext{
34 See David Reynolds, "The diplomacy of the Grand Alliance”, Richard J.B. Bosworth \& Joseph A. Maiolo (eds), The Cambridge History of the Second World War. Volume II. Politics and Ideology, Cambridge: Cambridge University Press, 2015, pp.301-323.

35 Histories of the cold war are legion. Particularly useful for questioning some of the more established approaches are John Lewis Gaddis, The Cold War. A New History, New York: Penguin, 2005; Jonathan Haslam, Russia's Cold War. From the October Revolution to the Fall of the Wall, New Haven: Yale University Press, 2011; and Odd Arne Westad (ed), Reviewing the Cold War. Approaches, Interpretations, Theory, London: Frank Cass, 2000. ${ }^{36}$ On the Cold War in the Third World, see Odd Arne Westad, The Global Cold War, Cambridge: Cambridge University Press, 2007.
} 
heart a competition about which system was the best, a competition defined in many people's minds as about which could best provide for its citizens the sort of standard of living and portfolio of freedoms to which they aspired. Central to this was economic performance, with each side straining to outperform the other, so the relationship was also one of economic competition. They were involved in a debate about both the most appropriate model of economic organisation and the nature of the society each wished to promote. ${ }^{37}$ Also important was the cultural sphere, which both sides sought to use to demonstrate the superiority of their respective systems. ${ }^{8}$ It was this ideological aspect of the Cold War that made it unlike previous confrontations, but that also made it relevant to the rest of the world in a way that a purely military confrontation was not.

The early decades of the Cold War was also the period of decolonisation, when large parts of Asia and Africa cut their colonial ties with their former European masters and embarked on the global scene as independent states. Both sides of the Cold War expended considerable energies on trying to sell the advantages of their own systems to the leaders of these newly independent states. In the 1960 s it was by no means clear which was the easier sell, Western capitalism or Soviet socialism. With the Soviet economy continuing to grow, a universal welfare and social support system, and a society that seemed to be advancing by leaps and bounds as symbolised by Soviet achievements in the space race-the launch of sputnik in 1957 and the first man in space in 1961-Khrushchev's boast that "we will bury you" struck a positive note among many in what came to be called the Third World. 39 The rejection of colonial domination seemed to go easily with appreciation of the advantages of the Soviet system; statedriven development seemed to promise rapid economic growth with the capacity to reshape society in accord with the elite's wishes, a heady combination for newlyemergent national leaders. The result was that there were real Western fears of significant Soviet advances in the Third World, and in the 1960s this fear seemed credible. In the words of Eric Hobsbawm, "A mere thirty to forty years after Lenin's arrival at the Finland Station in Petrograd, one third of humanity found itself living under regimes directly derived from the 'Ten Days That Shook the World' (Reed, 1919) and Lenin's organizational model, the Communist Party." 40

The basis for this had often actually been established earlier. Nationalist movements in the colonial territories were often headed by individuals who had been educated in the colonial metropole where they had been brought into contact with a range of ideas, including socialism. For some of them the Russian revolution was a catalytic experience, opening up a range of possibilities not open to them before, and persuading them to take up a socialist or even a communist stance. For example, many of the

\footnotetext{
37 This was illustrated by the famous Khrushchev-Nixon "kitchen debate" in 1959. For a transcript of the debate, see www.cnn.com/SPECIALS/cold.war/episodes/14/documents/debate/ cited in Charles S. Maier, "The world economy and the Cold War in the middle of the twentieth century”, Melvyn P. Leffler \& Odd Arne Westad (eds), The Cambridge History of the Cold War. Volume 1. Origins, Cambridge: Cambridge University Press, 2010, p.44 $3^{8}$ For an excellent summary of this, see Jessica C.E. Gienow-Hecht, "Culture and the Cold War in Europe", Leffler \& Westad, ibid, pp.398-419. Also see David caute, The Dancer Defects. The Struggle for Cultural Supremacy during the Cold War, Oxford: Oxford University Press, 2003.

39 In the sense that Khrushchev's comment could be better understood as "we will be present at your funeral." The attraction of the Soviet model, or at least some aspects of it, for post-independence leaders was reflected in the attention it received in much of the scholarly literature of the time. For example, John H. Kautsky, Political Change in Underdeveloped Countries. Nationalism and Communism, New York: John Wiley \& Sons Inc., 1962 and Irving Louis Horowitz, Three Worlds of Development. The Theory and Practice of International Stratification, New York: Oxford University Press, 1966.

40 Eric Hobsbawm, Age of Extremes. The Short Twentieth Century 1914-1991, London: Abacus, 1995, p.55. Hobsbawm's reference is to the classic eye-witness account of the revolution originally published in 1919, John Reed, Ten Days That Shook the World, Harmondsworth: Penguin, 1970.
} 
leaders of the Chinese revolution (like Zhou Enlai, Li Lisan and Deng Xiaoping) and of the Vietnamese revolution (including Ho Chi-Minh) along with post-colonial leaders in Franco-phone Africa like Leopold Senghor spent time in France, while many who came to head former British colonies were educated in Britain (for example, Lee Kwan Yew). ${ }^{41}$ Some, including Ho, even spent time in Moscow. For many such people, leftwing politics was almost the default position because it naturally aligned with anticolonialism, and this in turn lined up with the principles of the Russian revolution and the state which emanated from it.

Most of the fears of Western leaders proved to be unfounded. Very few of the former colonies actually became closely aligned with the Soviet Union. Even among those countries that adopted elements of the Soviet model, $4^{2}$ chiefly single party rule and a command economy, many did not become politically actively aligned with the Soviet Union. The major exception to this, and the one that most frightened Western leaders, was China. The Chinese Communist Party was established in 1921 on a wave of enthusiasm for the Russian revolution among left-wing Chinese intellectuals. It was this organisation that was victorious in 1949, creating the Chinese People's Republic and entering into an alliance with the USSR. Although the alliance was not to last, the creation of this new communist power changed the dynamic of the Cold War.

But the Chinese case was the exception rather than the rule; many Third World states sought to tread the path of neutrality rather than aligning themselves with one side in the Cold War. However this was not the perception in leading Western capitals in the 1960 s, 1970 s and into the 1980s. Western leaders were so used to interpreting global events through a paradigm of an expansionist Soviet Union, that most developments in the third world were seen in this way. This zero sum approach meant that where national liberation movements were fighting either against colonial rule or the postcolonial government, they were tarred with the brush of Soviet or Chinese agents. 43 This view was strengthened by the way the Soviet Union did often provide assistance to such movements, but Western decision-makers failed to see that such assistance did not automatically tie these groups closely to the Soviet Union.

This perception of expanding Soviet influence in the Third World fed directly back into the primary attitude to the Soviet Union on the part of Western leaders: the view of the USSR as an expansionist power held by most Western governments was reinforced by the wave of anti-Westernism in the Third World. The response was usually a strengthening of Western, especially American, military might. This had direct implications for Western societies, noted below. It also meant that until around 1989, military threat and the danger of a military outbreak remained a realistic possibility in the minds of many, policies like détente notwithstanding. The militarisation of international relations that was part of the Cold War was on the Western side a direct result of this perception of the Soviet Union as an expansionist power. 44

\footnotetext{
${ }^{41}$ So too were many of the intellectuals whose work provided theoretical underpinning for many of these leaders. Examples include Franz Fanon and Aimé Césaire.

$4^{2}$ For a comprehensive analysis that includes all of those countries that could be considered in this way, see Leslie Holmes, Politics in the Communist World, Oxford: Clarendon Press, 1986.

43 Probably the costliest instance of this was Vietnam. Stanley Karnow, Vietnam. A History, New York: The Viking Press, 1983, esp. ch.5.

44 This is not to deny that the Soviet side played a part in this militarisation, both through its own domestic military build up and through its attitude to the West, which it saw as being inherently anti-Soviet and aiming to destroy the USSR. For an interesting study of the early years of the cold war that focuses upon Soviet perceptions,
} 
This default position blinded Western policy makers to a more nuanced view of Soviet policy. By stereotyping the Soviet Union in this way, Western decision-makers were denied flexibility in understanding Soviet developments and inclined always to see those developments in the worst possible light. This is well illustrated by the difficulty many had in recognising the implications for major change involved in the rise of Mikhail Gorbachev to the Soviet leadership in 1985. The path travelled by Ronald Reagan shows that such blindness did not have to be permanent; he shifted from condemnation of the "evil empire" and the promotion of the "star wars" missile defence system in 1983 and the mock announcement of the imminent bombing of the USSR in 1984, to (along with Gorbachev) setting in train the end of the Cold War.45 But many Western statesmen had difficulty seeing beyond the established paradigm.

In this sense, the Cold War rested upon a Western view of the Soviet Union and a Soviet view of the West that stemmed essentially from the outcome of the Russian revolution: an expansionist, ideologically-driven power intent upon extending the sway of its ideology and national power across the globe, and a West as unalterably committed to the rollback of Soviet power and the overthrow of the Soviet regime. How accurate these views were is a matter of some dispute. As Soviet growth rates slowed and the dream of the communist future faded among its citizens, both from the late 1960s, its missionary zeal ebbed away, although its great power aspirations remained. And in this regard, it continually searched for advantage in the international arena, but this was not directly linked with the ideals emanating from the revolution. Nevertheless, Western decision-makers continued until the end of the 1980 s to see an expansionist power driven by ideological certitude even though such a paradigm distorted their understanding of what the country was really about.

This propensity to see the Soviet Union as inherently expansionist has unfortunately become so embedded in Western outlooks that it continues to infect policy towards Russia today. ${ }^{46}$ Within the West, the frame through which contemporary Russian actions is seen is overwhelmingly that notion of expansionism that was intrinsic to the view of the Soviet Union. In this regard, Russia is seen as a revanchist power, trying to recover the glories of the Soviet past, and Putin is cast as a throwback to that period who wants to restore the USSR. 47 Clearly Russia shares many of the geopolitical imperatives of the Soviet Union, and therefore many of the responses are likely to be similar. But this should not blind us to the very important differences between the two, including a political system with (limited) contestation, a hybrid state-private economy, the absence of a formal ideology, and the much greater freedom enjoyed by the populace. Russia is not the USSR-lite. The interpretation of Russian foreign policy remains a vexed question among scholars, ${ }^{48}$ but one thing that is clear is that assuming from the outset that Russia is an expansionist power hinders the ability to understand Russian action and intent. And to see it simplistically as seeking to restore the USSR,

see Vojtech Mastny, The Cold War and Soviet Insecurity. The Stalin Years, New York: Oxford University Press, 1996.

45 For a study of the Gorbachev-Reagan relationship by an insider, see Jack F. Matlock Jr, Reagan and Gorbachev. How the Cold War Ended, New York: Random House, 2004.

${ }^{46}$ For a cogent statement of the problem, see Jack F. Matlock Jr, Super-power Illusions. How Myths and False Ideologies Led America Astray - and How to Return to Reality, New Haven: Yale University Press, 2010.

47 For one example of this, see John Besemeres, A Difficult Neighbourhood. Essays on Russia and East-Central Europe Since World War II, Canberra: Australian National University Press, 2016.

${ }^{48}$ For example, compare Richard Sakwa, Frontline Ukraine. Crisis in the Borderlands, London: I.B. Tauris, 2015, and Marvin Kalb, Imperial Gamble. Putin, Ukraine, and the New Cold War, Washington DC: Brookings Institution Press, 2015. 
despite the nostalgia for that period and the continued use of some of the symbols of that era, is to misunderstand contemporary Russia and its leaders. In this sense, one hundred years on, Russia is still suffering under the paradigms of Western policy generated in response to the Russian revolution.

\section{The Revolution and Western Domestic Politics}

While global politics was shaped fundamentally by the Russian revolution, the state that emerged from that revolution and the reaction to it, so too was Western domestic politics. The revolution had a major influence on the development of left-wing and oppositionist politics in general in all the major countries of the West. Leftist politics had been present well before the revolution. Socialist and working class politics had been evident from early in the nineteenth century, 49 labour parties had been established in many countries including Britain in 1900 and Australia in 1901, the first labour government in the world came to power in Australia in 1904, while trade unions had been active in Britain from the eighteenth century. But the Russian revolution stimulated a new development, the emergence of a more organised extreme left wing of the labour movement.

The emergence of an organised extreme left around communist parties occurred in the wake of the Russian revolution. Spurred on by the success in Russia, activists formed communist parties in many of the countries of the West, including the US in 1919, Britain, France and Australia in 1920, and Italy in 1921. ${ }^{\circ}$ The emergence of such parties was a matter of major concern for governments of both right and left persuasions; the former because they opposed virtually everything the communists stood for, the latter because they feared both being outflanked on the left and infiltration and take over by communist activists (so-called "entrism"). As a result, communist organisations often operated under a series of legal and practical handicaps as their opponents sought to place obstacles in their way (see below). The communists generally played into the hands of their opponents because of the way they were often split on doctrinal issues and, after 1961, by their reaction to the Sino-Soviet split. At the same time the broader socialist left was split between those who thought the only path to power was through revolution while others believed in the "parliamentary road to socialism". The former, revolutionary, road was the one favoured by Moscow and pressed on local communist parties, although there were tactical departures from this line.

In most Western countries, the communist parties remained fringe organisations, with little popular support. Only in France and Italy did they become mainstream parties after the war. ${ }^{51}$ But the communist movement in most countries suffered a major blow in 1956 when Khrushchev's policy of destalinisation punctured the leftist image of the Soviet Union under Stalin, followed by the Soviet invasion of communist Hungary, and twelve years later of Czechoslovakia. For many within the communist movement, the Czech invasion marked the death knell of reform communism. Those parties like the French Communist Party that refused to condemn the invasion saw their support base

\footnotetext{
49 For example, see Stefano Bartolini, The Political Mobilization of the European Left, 186o-1980. The Class Cleavage, Cambridge: Cambridge University Press, 2000, and Geoff Eley, Forging Democracy. The History of the Left in Europe, 1850-2000, Oxford: Oxford University Press, 2002.

50 Priestland, op cit., ch.3; McAdams, op cit., ch.4; Brown, op cit., ch.5.

${ }^{51}$ For an interesting study of the context and differential success of left wing parties in Europe, see Tony Judt,

Postwar. A History of Europe Since 1945, London: Vintage Books, 2010.
} 
erode while the Italian party, that did reject this, underwent regeneration under a new leader. Nevertheless, there was widespread disillusionment within communist ranks in the wake of these developments, and many left..$^{2}$ The movement, ever fissiparous, was also hurt by the Sino-Soviet split, which became evident in the early 1960s and caused many national communist movements to split as people took sides in that dispute. These sorts of organisational problems reinforced the marginalisation of the communist movement in most Western societies.

But the importance of the communist movements in the West did not lie in the votes they could accumulate in elections. It lay in what those movements represented. They represented the ideals of the Russian revolution, the belief that a better society could be built than the one in which they lived, that the ills of poverty, unemployment, illiteracy and subjection were not inevitable. Into the 1960s, they represented hope, and the belief that the downtrodden were not destined to remain forever in the situation in which they found themselves. Things did not have to remain the way they were. In the wake of the 1929 depression and the Second World War, they seemed to promise hope for the future. Many intellectuals, among others, flocked to their banner in light of these appeals. 53 In this sense, the revolution was an important stimulus for the growth of a vibrant and creative leftist intelligentsia which was able to exercise significant influence on the public culture of Western democracies as well as to generate hope for a better world. They were central to such important debates as those about the relative role of state and market in the economy, the nature of democracy, and whether liberty was possible without equality. 54

Although these movements remained internally tendentious, argumentative and prone to splits, often over seemingly trivial ideological points, this history of division and infighting did not diminish the appeal of the ideals which had motivated them initially. These ideals provided an anchoring point for left politics in Western societies, in the sense that for those leftist forces closer to the mainstream of politics than the communists, those ideals represented the standard from which one could not deviate too much and retain the leftist banner. This does not mean that mainstream leftist forces, like the labour parties in Britain and Australia or social democratic parties in Europe, adopted communist ideology, but many of the positions they took on basic issues were extensions (usually in a more moderate direction) of positions enunciated by the communists. This is why it was relatively easy for people to move from the communist fold into the labour one; it did not involve the total rejection of all former positions, but the adoption of stances that were recognisably related to those they had taken before.

However this anchoring role was destroyed by two developments. First, the growth of post-class politics. As Western societies became ever more wealthy and distributive states were able to share some of that wealth around, living standards rose and the old bases upon which class politics had rested disintegrated. This occurred around the

\footnotetext{
$5^{2}$ On this question of disillusionment, see Paul Hollander, The End of Commitment. Intellectuals, Revolutionaries, and Political Morality, Chicago: Ivan R. Dee, 2006. For one person's explanation of why he left, see Howard Fast, The Naked God. The Writer and the Communist Party, New York: Frederick A. Praeger, 1957. For an interesting discussion of this period, including why he remained in the party, see Eric Hobsbawm, Interesting Times. A Twentieth Century Life, London: Abacus, 2002, ch.12.

53 See Paul Hollander, Political Pilgrims. Western Intellectuals in Search of the Good Society, Oxford: Oxford University Press, 1981, and Neal Wood, Communism and British Intellectuals, London: Victor Gollancz, 1959.

54 For a nice discussion that personalises this third debate, see David Caute, Isaac \& Isaiah. The Covert

Punishment of a Cold War Heretic, New Haven: Yale University Press, 2013.
} 
same time as post-Czechoslovak invasion disillusionment set in within the communist movement, meaning many on the left began to search for alternatives. They found them in growing movements like environmentalism, feminism, gay rights and even messianic religions. As "values" came to be seen as more important than "class" 55 and the affiliation of voters therefore became more problematic, the issue of what left-wing parties stood for became acute. This problem was exacerbated by the second development, the collapse of the Soviet Union and of communism in Europe (added to the shift away from communist principles in China, Vietnam and Cuba). With the collapse of the USSR, the Soviet experiment was widely deemed to be a failure. $5^{6} \mathrm{In}$ effect this was interpreted to mean that the ideals of the revolution were just that, ideals, and could not be realised in practice. The anchoring point for leftist politics in the West thereby disappeared, leaving left-wing politicians to flounder looking for something to stand for. Their problem is that without something like the ideals of the revolution, the positions they adopt appear to have little substance.

So the Russian revolution was crucial to the structuring of domestic politics in the West because its ideals constituted a source of stability for left--wing politics. It was also crucial domestically in two other senses. First, the political elites' fears about the "communist menace" were translated into measures designed to limit and restrict working class organisation and activity. Against a background of often powerful rhetoric about the "red threat", Western governments introduced various measures, including restrictions on labour union organisation and action, anti-strike provisions, measures against sedition and "pernicious political activities" (the US Hatch Act of 1939), limits on freedom of speech and assembly, and the banning or attempted banning of communist parties and their publications. 57 While no other Western state had the equivalent of the House Unamerican Activities Committee, with its blacklisting of communists and sympathisers, they were all characterised by these sorts of measures. This "red fear" also facilitated the growth of internal surveillance. The extensive surveillance state that has grown up recently in response to international terrorism was built on the foundations of the earlier scares about communism. Although the major domestic intelligence agencies were not created in specific response to the perceived threat from the left, they soon took this to be one of their major tasks, ${ }^{8}$ and during the Cold War, their resources were substantially enhanced.

Second, the attitudes that underpinned the Cold War discussed above were translated into the domestic political economy through means of high levels of defence spending, justified principally in terms of the arms race with the USSR.59 The distorting effect of such spending on economies is well known and occurred in all the major Western countries, although it was at its most extreme in the US. This emphasis upon defence came to be accepted as one of the facts of life of a modern economy. But the normalisation of defence spending in this way can lead not only to domestic

\footnotetext{
55 For example, see Ronald Inglehart, Modernization and Postmodernization. Cultural, Economic, and Political Change in 43 Societies, Princeton: Princeton University Press, 1997.

${ }^{5}$ Although not all were as triumphalist as Francis Fukuyama, The End of History and the Last Man, London: Penguin, 1992.

57 For some of this legislation in some European countries, see Giovanni Capoccia, Defending Democracy. Reactions to Extremism in Interwar Europe, Baltimore: The Johns Hopkins University Press, 2005, pp.256-264. Also Fischer, op cit.

$5^{8}$ For example, on MI5, see Christopher Andrew, The Defence of the Realm. The Authorized History of MI5, London: Allen Lane, 2009; and on the FBI, Fischer, op cit., pp.257-261.

59 For a discussion of this spending, see Todd Sandler \& Justin George, "Military Expenditure Trends for 19602014 and What They Reveal", Global Policy 7, 2, 2016, pp.174-184.
} 
distortions, but also potentially to international ones. This is illustrated by the way in which the Reagan Administration's plans to develop the "star wars" defence system, in addition to its other budgetary policies, massively increased US national debt and its reliance on the international economy. As the largest national economy, any dislocation in the US economy has a substantial ripple effect through the global economy, as the 2008 financial crisis demonstrated. Although the American view of the Soviet Union was not the sole cause of this development, it did play a significant part. The reaction on the part of Western ruling circles to the Soviet Union and what it was perceived to stand for has thus been an important factor in shaping both domestic political contours and the political economy of the contemporary Western state.

\section{Conclusion}

The Russian revolution was the most important development in the twentieth century. Not only did it shape the course of development of the geographically largest country in the world, but through the reaction of others to it, it shaped both the international relations and the domestic politics of the leading countries for almost a century. It also had a significant influence culturally, not only through the significant stimulus the revolution gave to avant garde art and culture more generally, ${ }^{60}$ but in the state promotion of such art forms as ballet, theatre, painting and architecture. The Soviet impact on culture was clearly not all positive-the deadening effect of socialist realism especially on literature and the constraints upon artists of all sorts were clearly not positive-but its cultural impact both domestically and internationally was significant.

But the continuing relevance of the revolution remains uncertain. Its role as the originator of an alternative form of modernity, and therefore as a major challenge to the liberal capitalist West, has passed. No longer does it make sense to see the revolution as the principal factor structuring international politics. But its legacy lives on in other ways. For example, the embedding of economic, social and cultural rights in international law reflects the earlier adoption of these in formal Soviet constitutional documents. In the economic sphere, the main alternative to some form of Western capitalism is one which combines state and private enterprise, as reflected in both contemporary Russia and China and having its roots in the Soviet experience. And as the Arab Spring of 2011 demonstrated, the notion of revolution remains a potential option in the eyes of many of those who feel disadvantaged by current political arrangements, and while revolution continues on the agenda, the example of 1917 will remain potent. After all, the values that underpinned revolution in 1917-equality, freedom, justice-remain relevant today, and if political leaders continue to ignore them, they may suffer the same fate as the vanquished of 1917.

\footnotetext{
${ }^{60}$ For example, see Yevgeny Kovtun, Avant Garde Art in Russia 1920-1930, Bournemouth: Parkstone Publications, 1996 and Anatole Kopp, Constructivist Architecture in the USSR, London: Academy Editions, 1985.
} 